\title{
The UN Framework Convention on Climate Change and the Paris Agreement: Challenges of the Conference of the Parties*
}

\author{
Lara Santos Zangerolame Taroco** \\ Ana Cecília Sabbá Colares ${ }^{* * *}$
}

Fecha de recepción: 5 de mayo de 2018

Fecha de evaluación: 2 de octubre de 2018

Fecha de aprobación: 2 de octubre de 2018

Artículo de reflexión

\begin{abstract}
The purpose of this article is to analyze, within the scope of the United Nations Framework Convention on Climate Change, how the Conference of the Parties provides a new locus for discussion within the International Environmental Law. Increasing scientific evidence about the possibility of global climate change in the 1980s led to growing awareness that human activities have been contributing to substantial increases in the atmospheric concentrations of greenhouse gases. Concerned with it, on December 11, 1990, the 45th session of the un General Assembly adopted a resolution that established the Intergovernmental
\end{abstract}

* This article is the result of the authors' participation in and observations at the 21st Conference of the Parties (COP21), and of research carried out as part of an institutional program for scientific initiation entitled: "The Conference of the Parties under the United Nations Framework Convention on Climate Change: The role of the IPCC and social repercussions of the meetings," led by Professor Luisa Cortar Simonetti Gonçalves and linked to the University of Law of Victoria and the University of Coimbra.

** Master of Laws (LL.M.) candidate in Law and Fundamental Guarantees at the University of Law of Victoria (FDV). Bachelor of Law (LL.B.) from the same institution. Member of the Research Group for Theoretical Criticism on Constitutionalism (CNPQ). Licensed Attorney. E-mail: larasantosz@hotmail.com

*** Master of Laws (LL.M.) in International Law from the University of Houston. Bachelor of Law (LL.B.) from the Pontifical Catholic University of Rio de Janeiro (Puc-Rio). Member of the International Association of Penal Law. Licensed Attorney. E-mail: anaceciliasabba@gmail.com 
Negotiating Committee for a Framework Convention on Climate Change (INC/FCCC). It was the beginning of the United Nations Framework Convention on Climate Change and also the beginning of the establishment of the Conferences of the Parties, which is currently in its 25th edition. The Paris Agreement was negotiated at the 21st edition of the Conference of the Parties and is the central theme of this study because of its relevance in the context of emission reduction. The Paris Agreement was created in December 2015, and the work on climate change had just begun. The final text of the Paris Agreement addresses important topics. Nonetheless, the document lacks clarity on many subjects, which were intentionally left aside in order to reach consensus to finish the Paris Committee's work. Considering this scenario and the challenges arising from this international treaty, the article analyzes the Conferences already held until the Paris Agreement. It also reviews the COP21 negotiations from 2015, taking into account a historical comprehension of the international concern over climate change, and the documents created by the Conference. Finally, this article discusses the developments and setbacks on the subject since 1997, and the objections made by international actors at the COP21 negotiations.

Keywords:International Environmental Law; Conference of the Parties; climate change.

Cómo citar: Zangerolame, L \& Sabbá, A (2019). The UN Framework Convention on Climate Change and the Paris Agreement: Challenges of the Conference of the Parties.Revista Prolegómenos, 22(43), 125-135.

\section{De la Convención marco de las Naciones Unidas sobre el cambio climático y el Acuerdo de París: los retos de la conferencia de las partes}

Resumen: El propósito de este artículo es analizar, dentro del alcance de la Convención Marco de las Naciones Unidas sobre el Cambio Climático, cómo la Conferencia de las Partes ofrece la oportunidad de desarrollar un nuevo lugar para el debate dentro del Derecho Ambiental Internacional. La creciente evidencia científica sobre la posibilidad del cambio climático global en la década de 1980 llevó a una creciente conciencia de que las actividades humanas han contribuido a aumentos sustanciales en las concentraciones atmosféricas de gases de efecto invernadero. Preocupada por ello, el 11 de diciembre de 1990, la 45a sesión de la Asamblea General de las Naciones Unidas adoptó una resolución que estableció el Comité Intergubernamental de Negociación de una Convención Marco sobre el Cambio Climático (INC/FCCC). Fue el comienzo de la Convención Marco de las Naciones Unidas sobre el Cambio Climático y también el inicio del establecimiento de las Conferencias de las Partes, que actualmente se encuentra en su vigésimo quinta edición. El Acuerdo de París se negoció en la vigésimo primera edición de la Conferencia de las Partes y es el tema central de este estudio debido a su relevancia en el contexto de las reducciones de emisiones. El Acuerdo de París se creó en diciembre de 2015 y el trabajo sobre el clima el cambio acababa de empezar. El texto final del Acuerdo de París aborda temas importantes. No obstante, el documento carece de claridad sobre muchos temas, que fueron dejados de lado intencionalmente para alcanzar un consenso para terminar el trabajo del Comité de París. Teniendo en cuenta este escenario y los desafíos derivados de este tratado internacional, el artículo analizará las Conferencias ya celebradas hasta el Acuerdo de París. También analizará las negociaciones de la cop21 a partir de 2015, teniendo en cuenta una comprensión histórica de la preocupación internacional por el cambio climático y los documentos creados por la Conferencia. Finalmente, este artículo también discutirá los desarrollos y contratiempos en el tema desde 1997 y los obstáculos impuestos por los actores internacionales en las negociaciones de la cop21.

Palabras clave: Derecho ambiental internacional; Conferencia de las Partes; cambio climático. 


\section{Da Convenção-Quadro das Nações Unidas sobre Mudança Climática ao Acordo de Paris: Desafios enfrentados pela Conferência das Partes}

Resumo: Este artigo avalia, no âmbito da Convenção-Quadro das Nações Unidas sobre Mudança do Clima, a maneira pela qual a Conferência das Partes (COP) fornece um novo lugar para a discussão do Direito Ambiental Internacional. Dentro deste contexto, o artigo examina todas as conferências realizadas até o Acordo de Paris. Também analisa as negociações da COP21 a partir de 2015, levando em conta uma compreensão histórica da preocupação internacional com as mudanças climáticas, bem como os documentos criados pela Conferência. Por fim, este artigo discute os desdobramentos e retrocessos sobre o tema desde 1997 e as objeções dos agentes internacionais nas negociações da COP21.

Palavras-chave: Mudança climática; Conferência das Partes; direito ambiental internacional. 


\section{Introduction}

During the 1990s, scientific evidence relating greenhouse gas (GHG) emissions to climate change caused public concern. The international community started to promote several international conferences that claimed the urgency of an international treaty to address the issue (Intergovernmental Panel on Climate Change, 1996). In 1990, the Intergovernmental Panel on Climate Change (IPCC), a respectable and well-known organization, published the first report on the matter (Intergovernmental Panel on Climate Change, 2007), explaining the probable increase in global average temperature. In the same year, the United Nations General Assembly (GA) created the Intergovernmental Negotiating Committee (INC) for an effective framework convention on climate change.

In 1992, one of the most important global meetings to discuss the environmental agenda and climate change took place in the city of Rio de Janeiro: the United Nations Conference on Environment and Development (UNCED), also known as Eco92 or Rio92. Twenty years after the pioneer Stockholm Conference, representatives of 108 countries met in Rio de Janeiro in 1992, with the intent to propose measures that could decrease environmental degradation and address global warming (Intergovernmental Panel on Climate Change, 2007).

During this Conference, the United Nations Framework Convention on Climate Change (UNFCCC) was adopted as a response to the alarming level of global warming due to anthropogenic actions. The signatory states (which today are 196) agreed to prepare a global strategy to protect the climate system for present and future generations under the precautionary principle, which is a guarantee against potential risks that cannot yet be recognized.

Article 7 of the UNFCCC established the Conference of the Parties (COP), the body responsible for implementing the Convention through action plans and reviewing its implementation annually. Until 2014, 21 Conferences had been held. These conferences considered the evaluative reports submitted by the IPCC, which plays a fundamental role in updating the debate. Also, the cop holds a central position on the discussion and recreation of International Environmental Law (IEL).

Therefore, the purpose of this study is to analyze how the COP, under the scope of the UNFCCC, provides a new place to discuss IEL, considering the Conferences held until the Paris Agreement (Mbengue, 2011). For this purpose, it is necessary to analyze the COP21 negotiations from 2015 with a historical comprehension of the international concern over climate change, and the documents created by the COP. Along these lines, it is possible to identify the advances and setbacks since 1997, as well as the obstacles that still persisted in the COP21 negotiations.

\section{Advances and challenges of the COP}

The interaction between economy and global environment is generally conflicting. This interaction shapes the logic and complexity of the climate change issue (Chayes \& Chayes, 1995). The main instruments to combat the impacts caused by climate change are the UNFCCC and the Kyoto Protocol, as well as the agreements and plans created by the COP.

However, before the COP started, 11 preparatory meetings were held, resulting in resolutions intended to guide the Conference's future work (Marengo \& Soares, 2003). The state parties prepared these resolutions to define starting points, elucidating many issues that are still barriers to agreements even after 20 years since the Conference's first edition (Kiss \& Shelton, 2007). Yet, member states need to address these difficulties in order to accomplish the Convention's goals.

\section{Goals of the UNFCCC and COP}

Eco92 was held to tackle issues raised at the Stockholm Conference in 1972. During this summit, participating states adopted the UNFCCC, setting several goals to meet challenges posed by global warming. According to Article 2 of the Convention, the COP aims to achieve: 
(...) stabilization of greenhouse gas concentrations in the atmosphere at a level that would prevent dangerous anthropogenic interference with the climate system. Such a level should be achieved within a time frame sufficient to allow ecosystems to adapt naturally to climate change, to ensure that food production is not threatened and to enable economic development to proceed in a sustainable manner (UNFCCC, 1992).

The Convention established goals and general rules, such as the actions that should be taken to reduce GHG emissions and mitigate the irreversible climate change (Hiskes, 2008). Nevertheless, as mentioned in the first section of this article, the elevated levels of GHG concentration in the atmosphere are the result of past economic activities.

Therefore, the Convention adopted the principle of common responsibility because mitigating and reversing climate change is a global duty, but set different standards depending on countries' development levels in order to attract developing countries to the discussion table (Hiskes, 2008). According to this understanding, Article 4 of the Convention differentiates three groups: Annex I Parties, made up of developed and industrialized countries; Annex II Parties, composed of developed countries that are part of the Organization for Economic Co-operation and Development (OECD); and Non-Annex I Parties, which are mostly developing countries. This is how the Convention distributed the responsibilities proposed on its preamble (Viola, 2002). Non-Annex I Parties do not have the obligation to reduce their GHG emissions under this division.

Article 7 institutes the COP, a specific body that examines member states' obligations periodically and issues reports and recommendations regarding the Convention's implementation; for instance:

1. A Conference of the Parties is hereby established.

2. The Conference of the Parties, as the supreme body of this Convention, shall keep under regular review the implementation of the Convention and any related legal instruments that the Conference of the Parties may adopt, and shall make, within its mandate, the decisions necessary to promote the effective implementation of the Convention (UNFCCC, 1992).

Thus, the COP is the supreme body of the Convention and consists in an association of all signatory member states of the treaty (Kiss \& Shelton, 2007). After its ratification in 1994, the parties started to meet annually since 1995, for a period of two weeks (IISD, 1995). The appearance of this new actor within International Law is a new event and reminds us of the Ramsar Convention of 1971, which predicted a similar structure in its Article 6 (IISD, 1996). This Conference can be distinguished from other diplomatic conferences on three aspects:

First, the COP is permanent, different from the classic ad hoc conferences held at diplomatic level. Continuity makes it possible to determine several structures and expectations related to periodic meetings and implementation reports. Until 2017, 23 cops have been held since 1995. This number shows the trustworthiness of these meetings (Yamin \& Depledge, 2004). Because of its duration, the Conference has the status of a "quasi-intergovernmental organization” (Sands, 2016).

Second, and differently from other diplomatic conferences, the cop's decisions are binding. Member states have hindered this possibility, alleging that decisions are not made through the traditional proceeding of treaty ratification and, therefore, could not be binding (Sands, 2016). However, it can be observed that the majority of cop's decisions are broadly tolerated as binding by member states and other international actors (Sands, 2016). Most of the international community agrees that these decisions reflect common interests and emanate a binding power.

The third aspect is the possibility of trade sanctions to secure the Conference's decisions. Non-observance of assumed obligations causes damages that affect the entire humanity; for instance, the whole world is seriously affected by GHG emissions, as informed by succeeding IPCC reports (IISD, 2015). However, the Convention provides "practicable steps" and avoids terms that suggest coercion 
and trade sanctions (Mbengue, 2011). Thus, this subject is still controversial.

The developed country Parties and other developed Parties included in Annex II shall take all practicable steps to promote, facilitate and finance, as appropriate, the transfer of, or access to, environmentally sound technologies and know-how to other Parties, particularly developing country Parties, to enable them to implement the provisions of the Convention (UNFCCC, 1992).

In conclusion, based on the abovementioned aspects, the COP was created to be different from other diplomatic meetings in the field.

\section{Behind the scenes of the cop: The Intergovernmental Negotiating Committee and the first meetings}

Retrospectively, in December 1990, during the 45th session of the United Nations General Assembly, the GA adopted a resolution that established the Intergovernmental Negotiating Committee (INC) for the UNFCCC. The United Nations Environment Programme and the World Meteorological Organization supported the resolution. One of the major results of the Committee meetings was the UNFCCC in 1991, which came into force in 1996, with the signature of 155 countries (IISD, 2015).

After adopting the Convention, the INC, made up of delegations of future signatory states, met five times to deliberate key points involving the Climate Convention, such as: member states' obligations covered by Article 4 of the treaty; financing mechanisms and technical support for developing countries; procedural and legal matters; and institutional organization (Earth Negotiations Bulletin, 1995).

Political and scientific challenges on climate change are several. During the Committee meetings, delegates already had difficulties related to the adoption of mechanisms to mitigate global warming (Keenlyside, Streck, \& Unger, 2016). The first scientific obstacle is choosing the best method to achieve carbon dioxide removal through sinks; for instance, forests and oceans. The second political challenge is implementing efficient energy technology and other necessary measures that require additional resources (mainly for developing countries) to obtain information, the know-how. It is a challenge due to a lack of financial resources to implement these mechanisms.

During 1994, the INC met twice in Geneva. At the first meeting, the INC, already at its ninth session, discussed the commitments set forth in Article 4 of the Framework Convention and criteria for its implementation. The INC also debated standards for joint implementation of mitigation measures by member states. Regarding the financial problem, the parties decided to focus on the concretization of Article 11 of the Convention and that, only when the treaty came into force in 1996, developing countries could request additional funds. Before that, the only effort towards developing countries' financial contribution would be broad support to maintain the Convention's Permanent Secretariat.

The obligations set out in Article 4 of the Framework Convention and the ways for their implementation involve issues related to capacity building as a means for developing countries to take action, as set forth in Article 11. This theme deserves to be highlighted because it will continue to be an essential point of discussion and disagreement over the next 20 years. Building capacity is a collaborative effort of all Parties, not limited to a transfer of capacities from developed to developing countries (Keenlyside, Streck, \& Unger, 2016).

At the 1994 second meeting, INC-10, the Committee agreed upon the first review instrument published by Annex I Parties. This instrument expressed the desire of these countries to enforce some commitments made by the treaties in order to adapt them to the best technology available (Earth Negotiations Bulletin, 1995). The major intention of these member states was to improve commitments set forth in Article 4 through an open text that would allow updates in the future. Some countries manifested that the first COP would be an opportunity to take on additional commitments. 
During INC-10, the parties also discussed the need to create an organization with specific goals, criteria, operational guidelines, functions, and institutions. The issue of financial mechanisms was mentioned again, and the countries determined that financing would happen on a "phaseby-phase" basis. The parties signed a temporary agreement between the Committee and the Global Environment Fund (GEF). Member states did not discuss further issues involving financing because, according to their delegates, they needed more deliberation (Earth Negotiations Bulletin, 1995), which could be better dealt with at the first cop.

INC-10 created the Subsidiary Body for Scientific and Technological Advice (sbsta). The sBsta analyzes information of technical and scientific evaluations from international bodies, such as the IPCC and the Subsidiary Body for Implementation (SBI) - responsible for making recommendations to the COP during the assessments and reviews of the Convention's implementation. At the end of INC-10, Trinidad and Tobago, representing the Alliance of Small Island States (AOSIS), submitted an additional protocol to the Interim Secretariat, asking for a determination to reduce GHG emissions by $20 \%$ until 2005 . The document impacted cop's meetings because it set difficult goals to be achieved and created divergences on future debates.

The 11th and last INC meeting took place in New York City in February 1995. This time, delegates debated several matters such as the Permanent Secretariat's location, cop's procedural rules, Article 4 commitments, and financial mechanisms. Regarding the definition of gef as a permanent entity responsible for financing, there was slight improvement compared to the projects presented by the Aosis. Delegates were not able to adjust Article 4 commitments to AOsIs's suggestions. They did not advance the discussion regarding the joint implementation of mitigation measures and did not define procedural rules.

INC meetings finished with gaps and uncertainty. The lack of success was a preview of future issues, which continued throughout multiple COP editions: AOsIs's discontent, financial difficulties, doubts upon joint implementation by member states, etc. In addition, the problem of how to create a method to remove carbon dioxide through sinks persisted. Through these reports for the COP1 preparation, it is possible to understand how climate discussions first begun. It permits to comprehend the reason for some barriers the international community still faces today, more than 20 years later.

\section{COP21 and the Paris Agreement: Perspectives and challenges for the future}

To understand the cop negotiations, some initial concepts are fundamental, such as the Ad Hoc Working Group on the Durban Platform for Enhanced Action (ADP). The ADP is a study group created by a subsidiary document drafted at COP 17 in 2011, whose main goal was to develop a protocol to be completed by 2015. The ADP's major goal was to create other binding instruments or agreements on climate change to be applied to all parties, such as the Framework Convention. The ADP's orientation, therefore, was to create this document at the 21st edition of the COP (COP21) (IISD Reporting Services, 2015).

The COP normally issues final reports on decisions throughout negotiations. These documents are part of the subsidiary normative body of the Conference and support climate actions until the next meeting. This practice took place since the first cop in Berlin, where the Berlin Mandate was established (IISD Reporting Services, 2015). The Mandate's principal focus is the consensus of all countries to take more energetic actions to mitigate the greenhouse effect.

Through resolutions, the parties decided that the developed countries' commitment to reduce their emissions to 1990 levels until 2000 would not be enough to achieve the Convention's longterm goals. Then, the parties created the Ad Hoc Group on the Berlin Mandate (AGBM) to encourage developed countries to reduce GHG emissions. The AGBM started to draft a protocol, which after eight meetings, was sent to cop3 to become the Kyoto Protocol. 
The same logic guided the ADP at COP21. The ADP finished negotiations and sent a draft agreement to COP21. The COP, at its 21 st edition, adopted by consensus this agreement, also known as the Paris Agreement. It contains precise reduction goals, long-term commitments, and specific previsions to transfer technology. It has legal force and also addresses financing and reimbursement for damages already caused by climate change.

The ADP became an incredibly famous abbreviation at the Conference halls. It was a result of a decision made by 196 countries at COP17 to commit with a long-term cooperation agreement. The agreement's main goal is to reduce emissions following specific standards until 2050. This plan had already been discussed at the Bali Action Plan, another subsidiary document from COP13 that provided guidance to member states, but only now was signed by all of them.

The draft Climate Agreement was concluded on October 23, 2015, in Bonn, Germany, where intersectional meetings were held to better prepare negotiations. The draft agreement structured a new legal instrument against climate change, giving member states the possibility to combat global warming until 2020.

Besides the Bonn's achievements, the Paris negotiations started with this document still limited due to 2,970 brackets, which showed dissent among member states. The ADP working group conducted the first week negotiations, passing this role to the Paris Committee in the second week. The Committee had to request support from the French government, which solved key points in order to avoid further conflicts that would bring negotiations beyond the Conference's deadline.

On December 12, 2015, on the last day of the 21st edition of the COP, the French Minister for Foreign Affairs and president of the Climate Conference, symbolically hit the presidency's table with a green leaf-shaped hammer. According to him, from that time, the world could count on a climate agreement. One hundred and ninety-six nations agreed to an unprecedented document to prevent and mitigate global warming: the Paris Agreement.
The document was finally created and the work on climate change had just begun. The final text of the Paris Agreement addresses important topics. Nonetheless, the document lacks clarity on many subjects, which were intentionally left aside in order to reach consensus to finish the Paris Committee's work.

It is important to observe that the Ad Hoc Working Group on the Paris Agreement acts in the same way as the ADP, which extinguished once its job was finished at COP21. The new group has to prepare the field in order to make the agreement come into force. It has responsibility for overseeing the implementation of the agreement's program and regularly informing the COP about its own work. The Agreement also provided working group sessions for 2016, alongside the subsidiary sessions of the Convention.

Additionally, the Agreement addresses the Intended Nationally Determined Contributions, also known as INDCs. The INDCs are documents on climate plans that should be disclosed by member states. These states, according to their national priorities, capacities, and circumstances, identify their national ambitions and possibilities to reduce GHG emissions and demonstrate how their goals would be achieved.

COP19 presented these voluntary goals (UNFCCC, 2015), but the deadline for submission was October 1, 2015 and not all participating countries submitted their updated plans, which are considered essential to achieve the Convention's goals. Therefore, the Agreement requires that those countries submit the document and mentions the concern that the estimated GHG emission levels for 2025 and 2030, according to the INDCs, are not enough to limit global warming between 1.5 and $2{ }^{\circ} \mathrm{C}$, as the treaty proposed.

Thus, countries' efforts need to go beyond the INDCS. They need to take further action to maintain the average global temperature increase below $2{ }^{\circ} \mathrm{C}$. The Paris Agreement also requires the IPCC to provide a special report in 2018, regarding the impacts of eventual global warming above $1.5^{\circ} \mathrm{C}$. The intention is to give scientific basis to future 
decisions and evaluations of the Paris Agreement working group.

The new climate document has nine topics: mitigation, adaptation, loss and damage, finance, technology development and transfer, capacity-building, transparency of action and support, global stocktake, and facilitating implementation and compliance. To achieve the goal to maintain the increase on average temperature between 1.5 and $2^{\circ} \mathrm{C}$ by the end of the century, the agreement established that all countries need to set national targets to reduce GHG emissions as soon as possible. Developed countries need to do it first. Developing nations will have more time. Although the parties did not estipulate a deadline, capacity-building mechanisms are necessary. Developing countries might need support, because they may have financial difficulties to implement these measures and are also vulnerable; for instance, the small islands, which are the first nations to be affected by climate change.

Until the second half of this century, it is necessary to find a balance between GHG emissions and the capacity to mitigate these gases, mainly carbon dioxide. The latter brings us to carbon storage mechanisms, defended by gas producing countries in order not to cut fossil fuels immediately.

The InDCs, essential to reduce GHG emissions, would be the instrument to enforce the new agreement. So far, 186 of 195 countries already have reduction plans for its GHG emissions. These reduction programs result on an average temperature increase by $3^{\circ} \mathrm{C}$ by the end of the century, for which member states need to review these contributions every five years. The first analysis will be done in 2018, and the first review, in 2020, when the Paris Agreement will come into force. It is mandatory that developed countries reduce their emission through national contributions. Developing nations are being encouraged to limit their emissions or reduce them according to their capabilities.

One of the main instruments of the agreement is the creation of inventories in order to follow national programs of GHG reduction (UNFCCC, 2015). Countries are divided into three categories: the developed ones, which need to provide complete information; emerging countries, which have to provide less information; and the non-developed ones, which have a minimum level of obligations.

The French Minister of Foreign Affairs, Laurent Fabius, publicly said the agreement is binding; the goals to reduce GHG emissions by country are not. He had to include this point in order to keep the United States in the agreement, the second highest carbon dioxide emitter in the world. The country would have problems to have the treaty ratified by the Congress if the Agreement imposed concrete goals to reduce GHG emissions.

For countries with fewer resources to adapt to the effects of climate change, and also reduce their emissions, the parties recognized the need for international cooperation. Other nations can also make voluntary concessions. The agreement provides that, until 2025, more than a hundred billion dollars will be collected annually, although a date for a review is not until the same year, 2025 (Green Climate Fund Briefing Note, 2011). At Cop16, the COP decided to establish the Green Climate Fund (GCF), with arrangements to be concluded between the cop and the gcf to "ensure that it is accountable to and functions under the guidance of the COP". It has the goal of mobilizing climate finance to support scaled-up mitigation and adaptation action in developing countries and its design was discussed in a special committee in October 2011 (Green Climate Fund Briefing Note, 2011). The gcf was designed to "support projects, programmes, policies and other activities in developing countries using thematic funding windows" (Green Climate Fund Briefing Note, 2011).

It is important to mention that in 2011 the gcf adopted its governing instrument, in which it recognized its objective to "promote the paradigm shift towards low emission and climate-resilient development pathways by providing support to developing countries to limit or reduce their greenhouse gas emissions and to adapt to the impacts of climate change" (Green Climate Fund Briefing Note, 2011). Concerning the Paris Agreement, it does not explicitly refer to the Green Climate Fund Briefing and the amount of funding that it is to mobilize. Especially in regard to values and how it 
will be treated, there is a pragmatic reason for this non-measurement.

The text recognizes in Art. 9.8 however that "the Financial Mechanism of the Convention, including its operating entities, shall serve as the financial mechanism of this Agreement" (UNFCCC, 2015). Thus,

The Paris Decision, serving as guidance for the implementation of the Paris Agreement and pre-2020 action, 'strongly urges developed country Parties to scale up their level of financial support, with a concrete roadmap to achieve the goal of jointly providing USD 100 billion annually by 2020 for mitigation and adaptation' (para 115). The Decision furthermore mentions that prior to 2025 the COP shall set a new 'collective quantified goal from a floor of USD 100 billion per year' (para 54) (Climate Focus, 2016)

The reason targets are missing from the actual Agreement is the condition of the United States. In doing so the Cop has enabled "the us President to adopt the Agreement as 'sole-executive agreement' under US law, without the requirement for the us Senate to approve" (Climate Focus, 2016). This was an important strategy to allow the agreement to be signed and avoid a situation like that of the Kyoto Protocol.

In the case of the Kyoto Protocol, the agreement never went into effect in the us because before the conference, the GOP-controlled Senate passed the Byrd-Hagel resolution in a 95 to 0 vote; it resolved that "the United States should not be a signatory to any protocol that mandated the reduction of greenhouse gas emissions unless it also required reductions from developing countries during the same time period" (Viola, 2002). It seems that the lesson from Kyoto's failure helped during the negotiations of the Paris Agreement.

Furthermore, the Agreement includes the maintenance of the Warsaw International Mechanism for Loss and Damage, created in 2013, at COP19. The mechanism is responsible for addressing loss and damage associated with climate change impacts, including disasters that make countries more vulnerable. The Executive Committee of the Warsaw International Mechanism should set up an information repository regarding transference risks and insurance, to facilitate the implementation of global strategies for risk management (IISD Reporting Services, 2015).

Additionally, the Agreement determines that the Executive Committee of Warsaw should work jointly with existing bodies, expert groups such as the Adaptation Committee, specialist groups, and appropriate organizations. The main goal is to prepare recommendations to prevent and minimize displacement due to climate change.

Because of its complexity, and the difficulty to reach a consensus during the COP21 negotiations, the agreement provided a specific mandate regarding loss and damage in the future, through the Warsaw Mechanism. This matter was concluded with another controversial topic. The decision stated clearly that loss and damage previsions do not provide a basis for liability and compensation of claims.

\section{Final considerations}

The climate issue, along with other economic aspects and global security, intensified international cooperation, a process that had been deflagrated since the end of World War II. Collective benefit requires actions that contradict states' individual interests. Climate change causes problems that are deeply related to common goods and global assets.

In this scenario, states worldwide started several initiatives to create mechanisms to adapt the world to the impacts caused by global warming. At the same time, the need to mitigate GHG emissions became a matter of international concern. Adapting to global warming and mitigating climate change are the main goals of the UNFCCC from 1992. The Convention reflects the first Evaluative Report from the IPCC, the competent body to evaluate climate change throughout the planet and, at the same time, guarantee the effectiveness of the adopted document.

The Convention started the construction of an effective climate change regime, consolidated through important foundations such as the COP. According to Article 7, the COP is the body responsible for the Convention's implementation. 
Among other functions, the COP is responsible for assisting member states in exchanging information and combating climate change and its effects. The establishment of international cooperation is fundamental to reduce GHG emissions and prevent higher levels of global warming. The dissent among states and the maintenance of current GHG emissions will cause severe damage to humankind.

For these reasons, the Paris Agreement intends to renew and recompose the topics for discussion. In view of existing economic conflicts, the Agreement asks for the prevalence of an environmental conscience and taking care of humanity's common assets. COP 21 was a milestone when it received 186 INDCS out of 195 parties. It was also a big step to achieve the UNFCCC goals, an idea debated since COP19.

Although the Paris Agreement's advances are considerable, there is still a long way to go in order for the treaty's provisions to be effective. From a historical analysis, it is possible to highlight an optimist view over the negotiation progress, having as a starting point positions disbelieving even the existence of climate change. Although the present is exciting when compared to past difficulties, it is necessary to transcend the scope of negotiations. Now, it is necessary to question if the time given to states to take action will be enough to mitigate, adapt, and reverse climate change.

The answer to this question is no. International actors are not acting at the same speed as the risks and disasters that put human beings on a vulnerable position. Humans suffer due to climate change on a daily basis. For a law based on the precautionary principle, it is necessary to do more. It is necessary to work harder for the agreement's implementation than we ever did for the agreement's creation. This is the only way to mitigate, adapt, and reverse the risks caused by climate change.

\section{REFERENCES}

Cepik, M. (2001). Segurança Nacional e Segurança Humana: problemas conceituais e consequências politicas, 1 .

Chayes, A. \& Chayes, A. H. (1995). The new sovereignty: compliance with international regulatory agreements. Cambridge: Harvard University Press.
Earth Negotiations Bulletin (1995). A reporting service for environment and development negotiations, 12(1). Canada: International Institute for Sustainable Development.

Hiskes, R. (2008). The Human Right to a Green Future: Environmental Rights and Intergenerationl Justice. Cambridge: Cambridge University Press.

Hohlfeldt, A., Martino, L., \& Fraca, V. (2001). Teorias da Comunicação: conceitos, escolas e tendências. Rio de Janeiro: Vozes.

IISD Reporting Services (1995). Summary of the First Conference of the Parties for the Framework Convention on Climate Change. Paris: Earth Negotiations Bulletin.

IISD Reporting Services (1996). Summary of the Second Conference of the Parties to the Framework Convention on Climate Change. Paris: Earth Negotiations Bulletin.

IISD Reporting Services (2015). Summary of the Paris Climate Change Conference. Paris: Earth Negotiations Bulletin.

Intergovernmental Panel on Climate Change (1996). The Science of Climate Change: Contribution of Working Group to the Second Assessment Report of the Intergovernmental Panel on Climate Change. Cambridge: Cambridge University Press.

Intergovernmental Panel on Climate Change (2007). Climate Change 2007: 4th Assessment Report of the Intergovernmental Panel on Climate Change. Retrieved from: http://IPCC.ch

Keenlyside, P., Streck, C., \& von Unger, M. (2016). The Paris Agreement: a new beginning. Journal for European Environmental \& Planning Law, 13.

Kiss, A. \& Shelton, D. (2007). Guide to international environmental law. Leiden: Martinus Nijhoff Publishers.

Marengo, J. A. \& Soares, W. (2003). Impacto das modificações da mudança climática. Síntese do Terceiro Relatório do IPCC. Condições climáticas e recursos hídricos no Norte do Brasil. Clima e Recursos Hídri$\cos$ 9. Porto Alegre: Associação Brasileira de Recursos Hídricos.

Mbengue, M. M. (2011). The Intergovernmental Panel on Climate Change (IPCC): A singular model of expertise at the international level. The transformation of international environmental law. Oxford-Paris: Hart Publishing.

Sands, P. (2016). Climate change and the rule of law: adjudicating the future in International Law. Oxford: Journal of Environmental Law. 
United Nations (1992). United Nations Framework Convention on Climate Change (UNFCCC). Retrieved from: http://unfccc.int

United Nations (2015). Paris Agreement on Climate Change. Retrieved from: https://unfccc.int/process-and-meetings/the-paris-agreement/the-paris-agreement

Viola, E. (2002). O Regime Interacional de Mudança Climática e o Brasil. Revista Brasileira de Ciências Sociais, 17(50).
Yamin, F., \& Depledge, J. (2004). The International Cimate Change Regime: A guide to Rules, Institutions and Procedures. Cambridge: Cambridge University Press. 